\author{
José Teixeira Cal Neto
}

\title{
Numerical Analysis of Ambrosetti-Prodi Type \\ Operators
}

Thesis presented to the Postgraduate Program in Mathematics of the Departamento de Matemática do Centro Técnico Científico da PUC-Rio as partial fulfillment of the requirements for the degree of Doutor

Advisor: Prof. Carlos Tomei 


\title{
José Teixeira Cal Neto
}

\section{Numerical Analysis of Ambrosetti-Prodi Type \\ Operators}

Thesis presented to the Postgraduate Program in Mathematics of the Departamento de Matemática do Centro Técnico Científico da PUC-Rio as partial fulfillment of the requirements for the degree of Doutor.

\author{
Prof. Carlos Tomei \\ Advisor \\ Departamento de Matemática - PUC-Rio \\ Prof. Djairo Guedes de Figueiredo \\ Instituto de Matemática, Estatística e Computação Científica - \\ UNICAMP \\ Prof. Henrique Versieux \\ Instituto de Matemática - UFRJ \\ Prof. João Marcos Bezerra do 0 \\ Departamento de Matemática - UFPB \\ Prof. Nicolau Corção Saldanha \\ Departamento de Matemática - PUC-Rio \\ Prof. José Eugenio Leal \\ Coordinator of the Centro Técnico Científico da PUC-Rio
}


All rights reserved.

\section{José Teixeira Cal Neto}

José Teixeira Cal Neto is a graduate of PUC-Rio, where he obtained the degrees of bachelor and master of science in Mathematics.

Bibliographic data

Cal Neto, José T.

Numerical Analysis of Ambrosetti-Prodi Type Operators / José Teixeira Cal Neto ; advisor: Carlos Tomei. - 2010. 49 f. : il. ; $30 \mathrm{~cm}$

Tese (Doutorado em Matemática Aplicada)-Pontifícia Universidade Católica do Rio de Janeiro, Rio de Janeiro, 2010. Inclui bibliografia

1. Matemática - Teses. 2. Análise Funcional Não Linear. 3. EDP's elípticas semi-lineares. I. Tomei, Carlos. II. Pontifícia Universidade Católica do Rio de Janeiro. Departamento de Matemática. III. Título. 


\section{Acknowledgments}

A $\mathrm{PhD}$ thesis is never accomplished individually. There are those who came before me, whose work I profited from, those who worked alongside me and hopefully those who will pick things up from here and advance it further.

Some might say a thesis is a journey, and in my case it certainly was. Let me start then by thanking all of those with whom I interacted at the Department of Mathematics of New York University as well as CAPES, for the financial support it provided. The PhD project was not concluded at NYU and would not have been possible without the unconditional support of my dear friend and advisor Prof. Carlos Tomei.

Carlos has been extremely generous over these three years we worked together, meeting me even at the expense of being away from his family during weekends. I am of course hugely indebted to his charming wife Laura and lovely daughter Letícia, always patient and hospitable whenever I dropped by to steal a beer or a slice of pizza.

Perhaps more than being an advisor, Carlos's greatest merit is that of being a friend and mentor to me, not only in these past three years, but throughout the twenty years we have known each other.

Though Carlos gets the most credit, all professors and fellow students at the department have been supportive of me and a big thank you goes to the Math Department in general. In particular, I would like to thank Prof. Carlos Frederico Palmeira, who has played a crucial role in my getting back to PUC after all these years. It was he who instructed me through the legalities of the process and who helped me obtain a teaching job at PUC to make up for the lack of financial support during the last three years. Prof. Nicolau Saldanha cannot be forgotten either. Though we interacted more in the early stages of the work, he was always supporting and also helped me balance my teaching load and research time.

Last but not least, to Creuza, Kátia, Orlando and Otávio, the Math. Department staff: Thank you for your help and for always laughing at my jokes, even the not-so-funny ones! 


\section{Abstract}

Cal Neto, José T.; Tomei, Carlos. Numerical Analysis of Ambrosetti-Prodi Type Operators. Rio de Janeiro, 2010. 49p. Tese de Doutorado - Departamento de Matemática, Pontifícia Universidade Católica do Rio de Janeiro.

Berger and Podolak obtained a geometric interpretation of the seminal result of Ambrosetti and Prodi regarding the behavior of solutions of certain semilinear elliptic partial differential equations. We consider extensions of such interpretation to develop a stable numerical algorithm that solves the equations.

\section{Keywords}

Nonlinear Functional Analysis; Semilinear elliptic PDE's; Numerical Analysis. 


\section{Resumo}

Cal Neto, José T.; Tomei, Carlos. Análise Numérica de Operadores do Tipo Ambrosetti-Prodi. Rio de Janeiro, 2010. 49p. Tese de Doutorado - Departamento de Matemática, Pontifícia Universidade Católica do Rio de Janeiro.

Berger e Podolak apresentaram uma interpretação geométrica do resultado seminal de Ambrosetti e Prodi sobre o comportamento das soluções de certas equações diferenciais parciais elípticas semi-lineares. Consideram-se extensões deste ponto de vista, a partir das quais se desenvolve um algoritmo numérico para resolver as equações.

\section{Palavras-chave}

Análise Funcional Não Linear; EDP’s elípticas semi-lineares; Análise Numérica. 


\section{Contents}

1 Introduction $\quad 10$

2 Basic Theory $\quad 14$

$\begin{array}{lll}2.1 & \text { Notation } & 14\end{array}$

$\begin{array}{lll}2.2 \text { Differentiability of Nemytskii Operators } & 15\end{array}$

3 The Problem $\quad 17$

$\begin{array}{lll}3.1 & \text { Some basic geometry } & 17\end{array}$

3.2 The Nonlinear Operator 19

$4 \quad$ Numerical Analysis $\quad 26$

4.1 An Inversion Algorithm 26

4.2 Finite Elements and Linear Algebra 29

$5 \quad$ Numerical Examples 33

5.1 Moving Horizontally 34

5.2 Moving along a fiber 35

5.3 Interacting With Two Eigenvalues 40

$\begin{array}{ll}\text { Bibliography } & 43\end{array}$

A A Quick Survey of the Finite Element Method 46

A.1 Variational Formulation 46

A.2 Triangulation and $\mathcal{P}_{1}$ Elements 47

A.3 Error Bounds, Convergence 48 
Alea Jacta Est

Gaius Julius Cæesar, Crossing the Rubicon River. 